\title{
Homeless people's social representations about self-care
}

\author{
Representações sociais de pessoas em situação de rua sobre "cuidar de si" \\ Representaciones sociales de personas en situación de calle acerca del "cuidar de si"
}

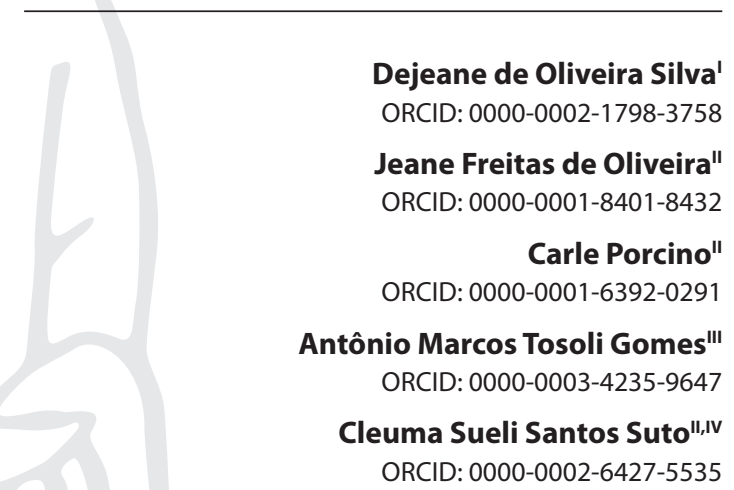

Evanilda Souza de Santana Carvalhov ORCID: 0000-0003-4564-0768

'Universidade Estadual de Santa Cruz. Ilhéus, Bahia, Brazil. "Universidade Federal da Bahia. Salvador, Bahia, Brazil.

I" Universidade do Estado do Rio de Janeiro. Rio de Janeiro,

Rio de Janeiro, Brazil.

"Universidade do Estado da Bahia. Senhor do Bonfim, Bahia, Brazil.

"Universidade Estadual de Feira de Santana. Feira de Santana, Bahia, Brazil.

How to cite this article: Silva DO, Oliveira JF, Porcino C, Gomes AMT, Suto CSS, Carvalho ESS. Homeless people's social representations about self-care. Rev Bras Enferm. 2020;73(1):e20180956.

doi: http://dx.doi.org/10.1590/0034-7167-2018-0956

\section{Corresponding Author: \\ Dejeane de Oliveira Silva \\ E-mail:dejeanebarros@yahoo.com.br}

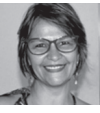

EDITOR IN CHIEF: Antonio José de Almeida Filho ASSOCIATE EDITOR: Dulce Aparecida Barbosa

Submission: 12-12-2018

Approval: 06-11-2019

\section{ABSTRACT}

Objectives:To capture and analyze the structure of homeless people's social representations about self-care. Methods: Research based on the theory of social representations, with 122 people in street situation. A semistructured questionnaire and free evocation technique were applied with the inducing words "caring for myself is". The evocations were processed by the software Evoc and Iramuteq, allowing to identify central and peripheral elements and the connection between them. Results: For the group studied, "feeding oneself, personal hygiene, protecting oneself and visiting the doctor" are actions and attitudes that represent caring for themselves. In the streets, "feeding oneself" is an essential action for living/surviving that underpins the others. Final considerations: Despite behaviors based on the biomedical model, self-care was represented by extended actions to meet basic human needs. This study offers elements of reflection to rethink care practices developed by health professionals.

Descriptors: Homelessness; Word Association Tests; Nurses; Self-Management; Vulnerable Populations.

\section{RESUMO}

Objetivos: apreender e analisar a estrutura das representações sociais de pessoas em situação de rua sobre o cuidado de si. Métodos: pesquisa fundamentada na teoria das representações sociais, com 122 pessoas em situação de rua. Aplicou-se questionário semiestruturado e técnica de evocações livres com o termo indutor "cuidar de mim é". As evocações foram processadas pelos softwares Evoc e Iramuteq, permitindo identificar elementos centrais, periféricos e a conexidade entre eles. Resultados: para o grupo pesquisado, "se alimentar, ter higiene pessoal, se prevenir e ir ao médico" são ações e atitudes que representam o cuidado de si. Nas ruas, "se alimentar" é uma ação essencial para (sobre)vivência que sustenta as demais. Considerações finais: apesar de comportamentos pautados no modelo biomédico, o cuidado de si foi representado por ações ampliadas para satisfazer as necessidades humanas básicas. Esse estudo oferece elementos de reflexão para repensar práticas de cuidado desenvolvidas por profissionais de saúde.

Descritores: Pessoas em Situação de Rua; Associação Livre; Enfermagem; Autocuidado; Populações Vulneráveis.

\section{RESUMEN}

Objetivos: comprender y evaluar la estructura de las representaciones sociales de personas en situación de calle acerca del cuidado de sí. Métodos: investigación con base en la teoría de las representaciones sociales, en la cual participaron 122 personas en situación de calle. Se aplicaron un cuestionario semiestructurado y la técnica de evocaciones libres con el término inductor "cuidar de mí es". Se procesaron las evocaciones en los softwares Evoc e Iramuteq, lo que permitió identificar los elementos centrales, periféricos y la conexión entre ellos. Resultados: para el grupo investigado, "alimentarse, tener higiene personal, prevenirse e ir al médico" son acciones y actitudes que representan el cuidado de uno mismo. En las calles, "alimentarse" es una acción esencial para la (super)vivencia que abarca las demás. Consideraciones finales: a pesar de comportamientos con base en el modelo biomédico, el cuidado de sí fue representado por acciones ampliadas para satisfacer las necesidades humanas básicas. Este estudio aporta elementos reflexivos para repensar las prácticas de cuidado desarrolladas por profesionales de la salud.

Descriptores: Personas sin Hogar; Asociación Libre; Enfermería; Autocuidado; Poblaciones Vulnerables. 


\section{INTRODUCTION}

The "people living in street situation" phenomenon is complex and increasingly common, requiring intra- and inter-sectoral actions with more effective and efficacious policies. Living and being on the streets generates diverse processes of prejudice, discrimination, fear, violence in all its dimensions and loss of basic human rights, such as access to health, education, housing, employment, income and leisure ${ }^{(1-2)}$. The contexts in which homeless people (HP) fit in, the ways they live and are in the world, reveal diverse self-care practices. Addressing self-care by those who live on the streets implies bringing to the fore elements of an ontological action of the human being (care) and of a social, historical, global, multifaceted phenomenon with social, political and economic implications (people in street situation).

The concept of care is a polysemic one, involving individual, social, (intra)subjective and cultural aspects, since it is a part of human existence. Self-care includes unique ways of being and living that involve diverse knowledge. Thus, it becomes relevant to consider an ecology of knowledge present in social relations ${ }^{(3)}$. In the face of this, common-sense knowledge, based on HP's experiences, brings with it subjectivities revealed in the daily life of interrelations with the street and with the other, expressed in the ways of caring for oneself and survive. Common-sense knowledge is legitimate and important in social life, as it elucidates and enables cognitive processes and social interactions, and permits changes in attitude and/or position taking both individually and collectively ${ }^{(4)}$.

Living on the street exposes women and men to risks and vulnerabilities that may influence and/or determine their living condition. It is important to note that, for the production of care, co-participation is an essential factor in the processes and decision-making, as people become implied in their own existence. In order to understand self-care as discussed here, one should not simply consider actions to treat diseases, since taking care of oneself in the health dimension is not limited to the conditions of falling ill(5).

For people who have the street as a place of permanent and/or circumstantial housing, having (or maintaining) health in such a vast connotation requires strategies that consider the ways HP are constituted in these places ${ }^{(6)}$. This population segment has particularities, which identify peculiar ways of life, and these should be considered in nursing interventions, whether in primary health care or services of high complexity, as well as in policy-making. This group is formed mostly by young, single men, with no income and fixed housing, with little or no relationship with relatives. In general, when street women become pregnant, they face the threat of being separated from their newborn by the Judiciary, causing suffering ${ }^{(7-8)}$. HP tend to use the body as the bargaining chip for drugs and/or money ${ }^{(9)}$.

This population group, due to a lack of fixed address and civil identification documents, is not included in the Census of the Brazilian Institute of Geography and Statistics and has difficulties accessing health services and government social programs ${ }^{(10-11)}$. These aspects hamper the planning of care actions and policies and maintain the social invisibility of the group. HP have unique expressions, but it is necessary to consider both the individual and collective aspects of relations, seeking to recognize the group's demands and needs. It is necessary to look at health and understand it in a broad perspective, considering the person, his/her context and the meaning given to what is represented, so that it becomes possible to understand/explain behaviors and symbolizations ${ }^{(12)}$.

The changes arising from the new concepts and perspectives on health, especially regarding the attempt to overcome the biomedical paradigm, brought about changes of image in the health field ${ }^{(13)}$. These transformations have led to re-significations in the expression of what is health and in the ways of caring for oneself and the other ${ }^{(12)}$. The practice of self-care permeates social representations (SR) of health and care. This requires the understanding of complex knowledge, articulated in a social dimension, which associate and mobilize repertoires anchored in values, beliefs, ideologies, ways of interpreting life, health and the dynamics of relationships with others ${ }^{(14)}$, with care and with the street. Life and the ways in which HP relate can impact their ways of moving and living life in this condition and the ways they experience health and self-care. Self-care has different interpretations and meanings as regards $\mathrm{HP}$, with ideas that are shared in the social context of relationships, whether with relatives, street mates, friends, professionals, social equipment, the street and its harsh rules for survival.

\section{OBJECTIVES}

To capture and analyze the structure of homeless people's social representations of self-care.

\section{METHODS}

\section{Ethical aspects}

The project was registered in Plataforma Brasil, analyzed and approved by the Ethics Committee of Research with Human Beings of the School of Nursing of Universidade Federal da Bahia, respecting all ethical precepts ${ }^{(15)}$.

\section{Theoretical-methodological reference}

This research study is based on the theory of social representations (TSR), whose focus is on the structural approach, called central core theory. This approach has as principle that a social representation is organized around a central core, composed of one or more elements that give meaning to the representation, providing to it a fundamental and inflexible sense ${ }^{(16)}$.

\section{Study design}

Descriptive and exploratory study of qualitative character.

\section{Study scenario}

The research was carried out in the Special Reference Center for Population in Situation of Street (Centro POP), located in the city of Ilhéus, Bahia, Brazil. 


\section{Data source}

A total of $122 \mathrm{HP}$ participated. The number of participants sought to meet the recommendation of studies based on the TSR of including more than 100 participants to generate a more stable prototypical analysis ${ }^{(17-18)}$. Inclusion criteria were: people of both sexes; of any gender identity; aged 18 years or over; and who were registered in Centro POP. And, as exclusion criteria: people who were not able to interact with the researcher; and those that showed refusal behavior at the time of approach.

\section{Data collection and organization}

The production of empirical data occurred from February to December 2017 and was carried out by the researcher herself. Two techniques were used: a questionnaire with characterization data; and the free evocation technique with the inducing words "to care for myself is". Individually the technique of free evocations was used, and participants were asked to say the first five words and/or phrases that came to mind when they heard the inducing words. Next, they should enumerate in order of importance the answers given and justify the most important ${ }^{(19)}$. Subsequently, the questionnaire was administered, with open and closed questions, so as to know the profile of the social group. This instrument was presented after free evocation, avoiding possible influences on data production. The instruments were applied in a reserved room at Centro POP, at a time agreed with each participant.

\section{Data analysis}

The evocations were submitted to two analytical techniques, namely: prototypical analysis, with processing in software Evoc version $2005^{(20)}$, allowing the construction of the four-cell board composed of central and peripheral elements. Evoc calculates and reports the simple frequency $(F)$ of occurrence of each word, the mean occurrence of each word in the order they were evoked, and the mean of the weighted mean orders of the set of words evoked (rang) ${ }^{(21-22)}$. The corpus processed in the Evoc software consisted of 610 evocations, of which 30 were different and 25 were flagged as more important, revealing a different word frequency corresponding to $4.91 \%$. In order to process the data, the minimum frequency of 10 and the mean frequency of 27 were considered. For the average of the mean orders of evocations (MOE), we considered 2.9 on a scale of 1 to 5 . The four-house board was organized on the basis of these data. The second technique was similarity analysis, aiming to reach the general structure of the representational field. The content of evocations was processed in Interface de R pour les Analyses Multidimensionnelles de Textes et de Questionnaires (Iramuteq), which allowed to visualize the links or connections between the various elements of the representational field and the identification of established co-occurrences between words ${ }^{(23)}$. The similarity index was calculated, which can be visualized in the maximum tree constructed from the highest indices or strongest connections between the different words ${ }^{(24)}$. This technique does not allow to confirm the centrality of words, but indicates the elements that are considered central by the group. The calculation is based on the number of co-occurrences between two evocations, divided by the number of participants, simultaneously, and the result of said calculation is the similarity index ${ }^{(25)}$.

\section{RESULTS}

Of the $122 \mathrm{HP}$ interviewed: $36 \%$ were from the Protestant Christian religion; $69 \%$ were between 18 and 39; 57\% were from Ilheus; $83 \%$ were of race/color brown/black; $64 \%$ singles; and $66 \%$ with incomplete elementary education. In addition, $81 \%$ have lived in street situation for 9 years; none of them had formal employment, $88 \%$ worked in the street, with emphasis on recycling and guarding and washing vehicles; $61 \%$ had one to three children; $71 \%$ monthly income of up to 200 reais; $70 \%$ maintained contact with relatives; $74 \%$ used psychoactive substances, especially alcohol $74 \%$ and marijuana $64 \% ; 82 \%$ sought health care; $42 \%$ have already had sexually transmitted infections (STIs), especially gonorrhea $69 \%$ and syphilis 35\%; 57\% used condoms; and 78\% have already suffered violence.

In relation to the investigated group's SR, the four-house board (Table 1) shows the central (upper left quadrant) and peripheral (other quadrants) elements related to the inducing term "caring for myself" inductor according to established criteria of analysis.

Table 1 - Four-house board to the inducing words "caring for myself is" in order of importance for people in street situation ( $N=122)$, llhéus, Bahia, Brazil, 2018

\begin{tabular}{|c|c|c|c|c|c|}
\hline \multicolumn{3}{|c|}{ Central core elements (freq. ${ }^{*} \geq 27$; MOE ${ }^{* *}<2.9$ ) } & \multicolumn{3}{|c|}{ Elements of the first periphery (freq. $\geq 27 ; \mathrm{MOE}=2.9$ ) } \\
\hline & Freq. & MOE & & Freq. & MOE \\
\hline Feed oneself & 72 & 2.736 & Sleep well & 51 & 3.353 \\
\hline Have personal hygiene & 58 & 2.310 & Be clean (drug-free) & 44 & 2.932 \\
\hline Prevent yourself & 35 & 2.657 & Work & 36 & 3.583 \\
\hline Visit the doctor & 27 & 2.074 & Exercises & 27 & 3.222 \\
\hline \multicolumn{3}{|c|}{ Contrast elements (freq. $<27$; MOE $<2.9$ ) } & \multicolumn{3}{|c|}{ Elements of the second periphery (freq. $\geq 27$; $M O E \geq 2.9$ ) } \\
\hline & Freq. & MOE & & Freq. & MOE \\
\hline Health follow-up & 26 & 2.615 & Have a home & 21 & 4.048 \\
\hline Not to drink & 25 & 2.840 & Take medicine & 17 & 3.118 \\
\hline Have good relations & 18 & 2.611 & Care for myself & 15 & 3.533 \\
\hline Brush teeth & 13 & 2.769 & Do the laundry & 14 & 3.571 \\
\hline \multirow[t]{3}{*}{ Important } & 10 & 1.300 & Distract the mind & 14 & 3.929 \\
\hline & & & Use a condom & 13 & 3.154 \\
\hline & & & Not to smoke & 10 & 3.200 \\
\hline
\end{tabular}

Note: ${ }^{*}$ Freq. $=$ frequency; ${ }^{* *} \mathrm{MOE}=$ mean order of evocations. 


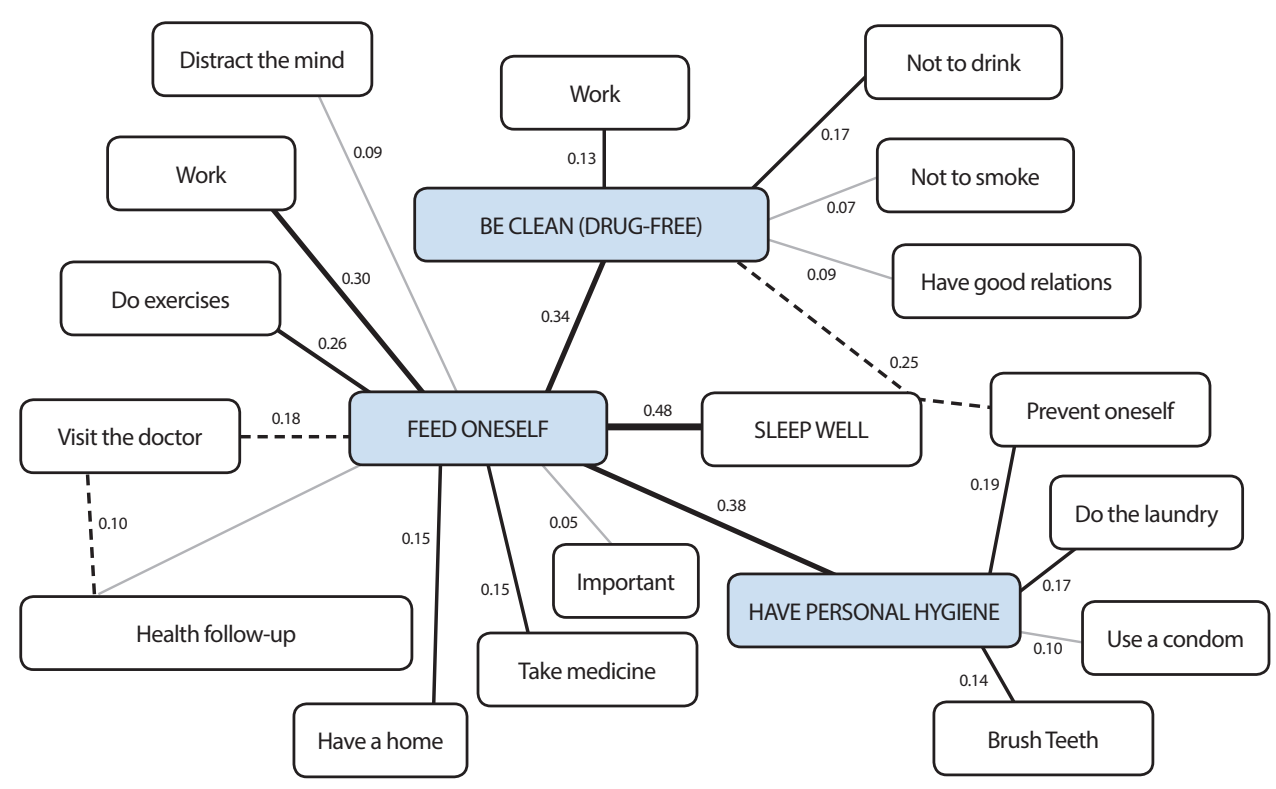

Figure 1 - Maximum similarity tree of free evocations by people in street situation $(N=122)$ to the inducing words "caring for me is", Ilhéus, Bahia, Brazil, 2018

Figure 1 is a graphical representation of the maximum similarity tree, where it is possible to visualize co-occurrences, from frequency analysis, resulting from the connection between words $^{(23-25)}$. For the inducing words "caring form me is", 76 of the 122 participants simultaneously evoked two or more words among those comprising Table 1.

\section{DISCUSSION}

The words that make up the probable central core and structure the social representation of self-care (Table 1) are: "feed oneself" ( $\mathrm{F}=72 ; \mathrm{MOE}=2.736)$; "have personal hygiene" ( $\mathrm{F}=58$; $\mathrm{MOE}=2.310)$; "prevent oneself $(\mathrm{F}=35 ; \mathrm{MOE}=2.657)$; and "visit the doctor" ( $F=27 ; M O E=2.074)$. The evocations "feed oneself" - according to its hierarchy as the most important for the group, due to the notable symbolic value for the represented object - and "visit the doctor" - the words more promptly evoked, with the lowest MOE (2.074) - proved to be relevant to self-care. These evocations are presented as consensual elements of the central core, since they feature as organizers of representation and determine the nature of the connections between the different words $^{(26)}$. Based on the words evoked and their location (Table 1), it can be inferred that "feeding oneself" is an essential action for self-care. However, for those who live (or survive) on the streets, having access to food is a daily challenge. The movements and relationships woven on the street will seek, a priori, the satisfaction of this need, evidenced by the attitude of asking, producing services or exchange relations for food. When participants accessed Centro POP, they were guaranteed three meals a day: breakfast, lunch and snack; however, often the food offered did not meet people'taste, desire or needs. In this context, food intake occurred as a way of meeting the demand of caring for oneself.

Even linked to Centro POP, HP were not guaranteed food on non-working days. These days, in order to feed themselves, they depended on shared information about places and times where food was offered, and they ran "money-making" activities such as cleaning, car guarding and recycling. In the street context, hunger, illness, sadness, pain, malnutrition and lowering of esteem coexist, resulting from a lack of access to adequate food to meet daily needs ${ }^{(27)}$. This reveals that the multiprofessional team plays a fundamental role in the integral care of HP, whether in primary health care or specialized services. A study carried out in the practice areas of Consultórios na Rua (Offices in the Street), in the city of Maceió, showed that one of the potentialities pointed out by users was the singularity in the service received ${ }^{(5)}$. This was also the reality of the participants in this study, noting that often, when seeking care, they did not have their needs met due to lack of documents or fixed housing, and this could contribute to their moving away from the units and aggravation of problems.

The words "visit the doctor" were the most readily evoked, explaining their presence in the central core. This characteristic denotes that representations of self-care are still present in a biologicist logic with a medicalizing mark in the belonging group. It can be inferred that the biomedical model is strong in established social relations and that this logic is reinforced both by health services, whose planning of actions is centered on the multicausal model, as well as by society ${ }^{(6,28)}$. Thus, the expression "visit the doctor" poses a challenge for HP due to difficulties in accessing health services due to the prejudices and stereotypes faced, difficulties in presenting oneself clean, lack of a fixed address, and lack of documents. A strategy used by the Federal Government was the enactment of Law no. 13.714/2018, which made it compulsory to care for people in situations of vulnerability, without proof of domicile ${ }^{(29)}$. A study carried out with HP in the city of Salvador, Bahia, showed that one of the problems faced by the social group investigated was the difficult access to services, denouncing the experience of the "paper citizen"(10,30), which enhances the processes of social exclusion, vulnerabilities and invisibilities. For self-care, it is important that each individual engages in self-care so as not to forget who one is and can take care of oneself properly ${ }^{(31)}$.

The words "have personal hygiene" $(\mathrm{F}=58 ; \mathrm{MOE}=2.310)$ and "prevent oneself" ( $F=35 ; \mathrm{MOE}=2.657)$ appear with a high frequency (Table 1), occupying the quadrant that corresponds to the central core. These evocations symbolize an attitudinal dimension, directed to the physical/ biological body, with socially established behaviors and actions such as: brushing teeth, bathing, using condoms, among others. These behaviors may represent an improvement in HP's quality of life and health, since their morbidity 
and mortality rates are higher than in the general population ${ }^{(32)}$. HP are likely to develop or enhance the onset of mental disorders, psychoactive substance use, STIs, tuberculosis, violence(s), and other social and health vulnerabilities ${ }^{(32-34)}$. Prevention, safety and hygiene attitudes show the consensus of the group investigated, as well as the incorporation of the object represented in social practices, whether consensual or nonconsensual.

According to participants, prevention is based on practices such as: using condoms, doing tests, brushing teeth, bathing, vaccination, not using drugs, among others. These findings are in agreement with research carried out with HP in the city of Salvador, Bahia, on health care and STI prevention ${ }^{(10)}$. Despite the notion of prevention exposed by HP, their vulnerability condition exposes them to risks as well as to violation of rights. Self-care manifested by HP shows self-preoccupation as an important social exercise, and it can be inferred that the meaning attributed to the represented object exposes extended actions of care that transcend the barriers imposed inby the experience(s) in street situation. The set of words that compose the central core evidences that, for the investigated group, self-care has is strongly related to the satisfaction of basic human and health needs and are not limited to the absence of diseases. Although there are evocations that reveal the biomedical perspective, associating care to treat/cure diseases, expressed by the words "visit the doctor", other evocations link self-care to everyday practices related to their particular context, considering issues of social and cultural order according to individual needs. The set of evocations that make up Table 1 outlines a logic of self-care that connects HP to their social environment and context of life. These evocations point out that self-care is revealed through the adoption of practices, behaviors, attitudes and ways of life symbolized in actions incorporated into the daily life of this group.

According to the fundamentals of the structural approach, the peripheral system is more responsive to the immediate context, being composed of more accessible, alive and concrete elements ${ }^{(16,26)}$. In the contrast zone (lower left quadrant of Table 1), the evocations "follow-up health" $(\mathrm{F}=26$; $\mathrm{MOE}=2.615)$, "not to drink" (F = 25; MOE = 2.840), "to have good relations" $(\mathrm{F}=18 ; \mathrm{MOE}=2.611)$, "brush teeth" $(\mathrm{F}=13 ; \mathrm{MOE}=2.769)$ and "important" (F = 10; MOE = 1.300). Although the elements that integrate this quadrant have been stated by a smaller number of subjects, they were referred to as very important ${ }^{(16)}$. The expression "health follow-up", in an imaginary dimension, can ratify the central core through the words "prevent" and "visit the doctor" and relate to HP's attitudinal dimension towards care. The evocation "not to drink" was the second most frequent among the words evoked. For participants, abstaining from alcohol contributes to positive attitudes in self-care, such as eating, bathing, sleeping, working, preventing oneself. Studies carried out with HP on the use of alcohol and other drugs indicate that this behavior is an alternative for street survival ${ }^{(7,35-37)}$. The words "good relations" were the third most evoked, revealing the need to avoid confusion, not to fight, know what to see and what to speak on the streets, as well as to define who to hang around with, thus protecting themselves from situations of violence and/or trouble.

The words "brush teeth" also reinforce the central core with a strong connection to the phrase "have personal hygiene". On the street, people struggle to meet their needs, especially when it comes to bathing and oral care, often leading them not to practice self-care, making them dirty, smelly, exposed to prejudices and turning away. This reality was evidenced in studies with HP in the cities of São Paulo and Salvador ${ }^{(10-11)}$. Nevertheless, the social group recognizes these practices as important and seeks to perform them. The processes of subjectivation by which participants' consciousness is constructed and transformed will guide their actions or induce destructive behavior ${ }^{(4)}$. It can be seen that, despite the barriers they encounter, HP practice selfcare, as shown in the representations captured here, without, however, resigning themselves to their reality. Among the 20 words that comprise Table 1, the cognition "important" was the most readily evoked, with the lowest $\operatorname{MOE}(1,300)$, and self-care is something very "important" in an evaluative dimension. The word expresses a rootedness in HP's ways of life, visible through the attitudes and behaviors that permeate the practice of selfcare. The analysis of the contrast zone suggests the absence of a subgroup, as the words complement each other, approximate and reinforce those located in the central core.

The first periphery (upper right quadrant of Table 1) is composed of elements which, although having a high frequency, were not readily evoked. In this research, the evocations that make up this first periphery present an attitudinal/behavioral dimension, expressed by the words "sleep well", "exercise" and "clean" (no drugs), while the expression "work" signals an attitudinal and purposive dimension. The words reveal that, in the group's collective memory, self-care demands the need to sleep well $(F=38 ; M O E=3.711)$. Sleeping on the street is a practice that generates doubts, anxieties, fears and search for suitable places by those who use this space as housing. In this study, women and men reported that they seek someplace "safe" and hidden to spend the night. At this juncture, caring for oneself on the street means being able to sleep, even though there are no doors and windows on the streets that guarantee security and privacy ${ }^{(1,28)}$; and not using drugs, thus being able to wake up "clean", work and exercise. These behaviors allow the encounter with extended care, symbolized by the study participants.

The word "clean" (drug-free) $(F=44 ; \mathrm{MOE}=2.932)$, the second most frequent word, brings the group's normative dimension of SR, being fundamental for care. In this study, drug use was the third largest cause of going and living on the streets, but for the social group investigated, non-use is revealed as a practice of care. Although they refer to this word, most use drugs, especially alcohol (74\%). In this sense, there is self-care that is based on abstaining from drugs as a positive strategy and there is self-care that is anchored in using drugs as a tool to face the street and its difficulties and facilitate socialization ${ }^{(7,36)}$. The word "work" $(\mathrm{F}=36 ; \mathrm{MOE}=3.583)$ is important, and the characterization data indicate that $88 \%$ of the $122 \mathrm{HP}$ that composed this study were engaged in paid activity. Although they do not have formal jobs, informal activities are part of their routines, they are essential for subsistence and signaled as being of prime importance to those who seek to leave the streets. Similar data were found in a study carried out with elderly people from western Pará, when work was among the main practices to have health as a form of care maintenance ${ }^{(14)}$. The evocation "doing exercises" $(F=27 ; \mathrm{MOE}=3.222)$ 
is related to the quality of life and the possibility of not having problems aggravated in the streets, since treatment of diseases was reported by participants as very difficult. This conception of disease prevention appears as a motivating element for the practices of walking on the beach, using public exercise equipment, and playing soccer ( $b a b a$ ) with friends. Doing physical activities has been widely emphasized by the media and also in research results that associate it with health ${ }^{(38)}$. Thus, this information is everywhere and becomes part of the life routine of those who live on the streets as well.

The second periphery - lower right quadrant - features elements with low frequency and evoked late, being less important for the group ${ }^{(26)}$. In this quadrant, one finds "have a home" $(F=21 ; M O E=4.048)$, "take medicine" $(F=17 ; M O E=3.118)$, "care for myself" ( $F=15 ; \mathrm{MOE}=3.533)$, "do the laundry" ( $\mathrm{F}=$ 14; $\mathrm{MOE}=3.571)$; "distract the mind" $(\mathrm{F}=14 ; \mathrm{MOE}=3.929)$, "use a condom" ( $F=13 ; \mathrm{MOE}=3.154)$ and "not to smoke" $(\mathrm{F}=10$; $\mathrm{MOE}=3,200)$. These words are consonant with the probable central core of the representation, as well as with the other words (Table 1), and with the maximum tree of similarity, observing the established connections between them. The similarity tree (Figure 1 ) is structured by three sets of themes that generate meaning and organize the other elements of self-care representation:"feed oneself", "have personal hygiene" and "be clean (drug-free)". The words "feed oneself" present the greatest centrality and have 11 connections, reaffirming its importance in the internal organization of representation. These characteristics signal the remarkable link between object and its representation ${ }^{(26)}$. Its highest indexes of similarity and strong connectedness were with "personal hygiene" (0.38), evocation also present in the central core (Table 1), "sleep well" (0.48), "clean (drug-free)" (0.34), "work" (0.30) and "exercise" (0.26), present in the first periphery.

The second word with most connections was "clean (drugfree)", with a total of six, having a high similarity index with "feed oneself" (0.34), "sleep well" (0.25) and "not to drink"(0.17). The words " have personal hygiene", present in the central core, were the third with the greatest number of connections, a total of five, especially the indices "feed oneself" $(0,38)$, "prevent oneself" $(0$ , 19) and "do the laundry" (0.17). The words "sleep well" and "be clean (drug-free)" are strongly connected with other words and, because they are in the first periphery of Table 1, they are very likely a part of the central core or have already comprised at some moment. However, other centrality tests, based on a return to the field, need to be carried out for confirmation. All these elements express self-care, revealed in HP's occupation with themselves and that takes place in movements of resistance and survival.

Shared experiences, culture, beliefs, knowledge, and individual values are symbolized in representations and practices that reflect new arrangements in ways of caring for oneself and another. This is experienced in a unique way by every person who lives on the streets and requires from care services encounters that empower the subjects, through the construction of dialogues that favor their power of agency, autonomy and self-determination. Caring for oneself on the streets brings a difficult reality that evidences the emergence of shared knowledge and action, with concrete attitudes of the various sectors of health, safety, education, social promotion and human rights. In order to ensure that these people's (in)visibility is not confronted with hygienic actions, it is necessary to guarantee forms of self-care, social (re)insertion, reestablishment of links, promotion of employment, income and citizenship, if we understand it as the full participation of the person in society.

In the general context of the structure of SR, it is understood from the established connections that self-care is important, anchored in the need to have access to food as the driving force to work, to struggle to have a home (for those who so desire) in which it is possible to sleep well and maintain personal hygiene. In the scope of extended personal hygiene, it is necessary to prevented oneself with basic actions, such as doing the laundry, brushing teeth and protecting oneself from an STI/unwanted pregnancy. In order for food to be a propeller, it is necessary not only to clean the body, but also to clean it chemically (be drug-free), not to drink and not to smoke, with the possibility of having good relation in a street situation. In the streets, the quest for survival reinforces social mechanisms and forms that are consistent with social and economic reorganization practices plausible with the singular needs and possibilities of each person ${ }^{(6.39)}$. Representations about self-care exhibit peculiar ways of caring for oneself and living and surviving in the streets.

\section{Limitation of the study}

The data here cannot be generalized to all HP in view of their pluralities and singularities, but can be generalized to the social group investigated, considering the geographic aspects of Ilhéus as a port and tourist city in southern Bahia. Although the study was carried out in a single municipality, it involved an expressive number of HP. One of the limiting factors was the fact that an average of 500 people were registered at Centro POP, but only 122 could be contacted, given the floating and migratory character of this population segment.

\section{Contributions to the area of nursing, health or public policy}

Health care runs through self-care, as an action of autonomy. The data produced here reflect information relevant to the proposal of more effective policies and actions for the care of HP. Life in the streets is a social problem, with demands for public health and for professionals who work at the different levels of health services, especially in primary health care. The placement of the nurse in Centro POP is fundamental for the integrality of actions. Although the service structuring ordinance does not clearly include this specialty, this research indicates such a need. In this sense, addressing the topic of self-care with the theoretical foundation of TSR's structural approach made it possible to understand the specificities of self-care practices adopted by the group, in consonance with the context in which they occur. This allows the health team, especially the nursing team, to approach care as a day-to-day construction, in order to minimize risks and health problems.

\section{FINAL CONSIDERATIONS}

This research made it possible to apprehend elements that make up the social representation of street people about caring for themselves. The data presented evidences the specificities of 
the investigated group, while at the same time they provide elements of reflection for the practice of health care developed by health professionals for the population group in focus. Self-care, for the investigated group, is represented by attitudes that favor the basic human needs (food, sleep, home, work) and hygiene, especially corporal (bathing, brushing teeth, doing the laundry). In addition, prevention measures for health problems (not drinking, not smoking, staying clean (durg-free), using condoms, exercising) and access to health services, focusing on the medical professional (visit the doctor, health follow-up), have great relevance. These are attitudes widely disseminated by health professionals and the media, whose life context reveals self-care as a daily construction. It is worth noting the group's focus on eating, revealing this a basic need of people in street situation, which should be considered by health professionals as they seek strategies to get closer and strengthen links.

\section{REFERENCES}

1. Oliveira DM, Expedito AC, Aleixo MT, Carneiro NS, Jesus MCP, Merighi MAB. Needs, expectations and care production of people in street situation. Rev Bras Enferm [Internet]. 2018;71(Suppl 6):2689-97. [Thematic Issue: Good practices in the care process as the centrality of the Nursing] doi: 10.1590/0034-7167-2017-0612

2. Borysow IC, Furtado JP. Access, equity and social cohesion: evaluation of intersectoral strategies for people experiencing homelessness. Rev Esc Enferm USP. 2014;48(6):1066-76. doi: 10.1590/S0080-623420140000700015

3. Santos BS. A gramática do tempo: para uma nova cultura política. 3rd ed. São Paulo: Cortez; 2010.

4. Jodelet D. Representações sociais: um domínio em expansão. In: Jodelet D, editor. As representações sociais. Rio de Janeiro: EdUERJ; 2001. p. $17-44$.

5. Ferreira CPS, Rozendo CA, Melo GB. A Street Clinic in a state capital in Northeast Brazil from the perspective of homeless people. Cad Saúde Pública. 2016;32(8):e00070515. doi: 10.1590/0102-311X00070515

6. Paiva IKS, Lira CDG, Justino JMR, Miranda MGO, Saraiva AKM. Homeless people's right to health: reflections on the problems and components. Ciênc Saúde Colet. 2016;21(8):2595-606. doi: 10.1590/1413-81232015218.06892015

7. Biscotto PR, Jesus MCP, Silva MH, Oliveira DM, Merighi MAB. Understanding of the life experience of homeless women. Rev Esc Enferm USP. 2016;50(5):749-55. doi: 10.1590/s0080-623420160000600006

8. Dotson HM. Homeless women, parents, and children: a triangulation approach analyzing factors influencing homelessness and child separation. J Poverty. 2011;15(3):241-58. doi: 10.1080/10875549.2011.588489

9. Bastos FI, Bertoni N. Pesquisa nacional sobre o uso de crack: quem são os usuários de crack e/ou similares do Brasil? Quantos são nas capitais brasileiras? Rio de Janeiro: Instituto de Comunicação e Informação Científica e Tecnológica em Saúde; 2014.

10. Silva ICN, Santos MVS, Campos LCM, Silva DO, Porcino CA, Oliveira JF. Social representations of health care by homeless people. Rev EsC Enferm USP. 2018;52:e03314. doi: 10.1590/s1980-220×2017023703314

11. Hino P, Santos JO, Rosa AS. People living on the street from the health point of view. Rev Bras Enferm [Internet]. 2018;71(Suppl 1):684-92. [Thematic Issue: Contributions and challenges of nursing practices in collective health] doi: 10.1590/0034-7167-2017-054712

12. Arruda A. Novos significados da saúde e as representações sociais. In: Sousa CP, Ens RT, Villas Bôas L, Novaes AO, Stanich KAB, editores. Angela Arruda e as representações sociais: estudos selecionados. Curitiba: Champagnat; 2014. p. 315-26.

13. Moscovici S. Representações sociais: investigações em psicologia social. 10th ed. Petrópolis: Vozes; 2013.

14. Tura LFR, Bursztyn I, Carvalho DM, Arruda A, Silva AO. Social representations on health built by the elderly of western Pará state, Brazil. Rev Bras Geriatr Gerontol. 2011;14(4):743-52. doi: 10.1590/S1809-98232011000400013

15. Ministério da Saúde (BR).. Resolução no 466 de 12 de dezembro de 2012. Aprova normas regulamentadoras de pesquisas envolvendo seres humanos [Internet]. Brasília: Ministério da Saúde; 2012 [cited 2018 Dec 01]. Available from: http://bvsms.saude.gov.br/bvs/saudelegis/ cns/2013/res0466_12_12_2012.html

16. Abric JC. L'approche structurale des représentations sociales: développements récents. Psychol Soc. 2001;4(12):81-103.

17. Wachelke J, Wolter R. Critérios de construção e relato da análise prototípica para representações sociais. Psic Teor Pesq. 2011;27(4):521-6. doi: 10.1590/S0102-37722011000400017

18. Gomes AMT, Oliveira DC, Sá CP. Social representations of the Brazilian national health care system in the city of Rio de Janeiro, Brazil, according to the structural approach. Rev Latino-Am Enfermagem. 2008;16(1):122-9. doi: 10.1590/S0104-11692008000100019

19. Nóbrega SM, Coutinho MPL. A técnica de associação livre de palavras. In: Coutinho MPL, Saraiva ERA, editores. Métodos de pesquisa em psicologia social: perspectivas qualitativas e quantitativas. João Pessoa: Editora UFPB; 2011. p. 95-106.

20. Vergès P. Ensemble de programmes permettant l'analyse des évocations: manuel d'utilisateur. Aix en Provence: Université Aix en Provence; 2003.

21. Wolter RP, Wachelke J, Naiff D. A abordagem estrutural das representações sociais e o modelo dos esquemas cognitivos de base: perspectivas teóricas e utilização empírica. Temas Psicol. 2016;24(3):1139-52. doi: 10.9788/TP2016.3-18

22. Costa TL, Oliveira DC, Formozo GA. Quality of life and AIDS from the perspective of persons living with HIV: a preliminary contribution by the structural approach to social representations. Cad Saúde Pública. 2015;31(2):365-76. doi: 10.1590/0102-311X00180613 
Homeless people's social representations about self-care Silva DO, Oliveira JF, Porcino C, Gomes AMT, Suto CSS, Carvalho ESS.

23. Camargo BV, Justo AM. Iramuteq: a free software for analysis of textual data. Temas Psicol. 2013;21(2):513-8. doi: 10.9788/TP2013.2-16

24. Rouquette ML, Rateau P. Introduction à l'étude des represéntations sociales. Grenoble: Presses Universitaires de Grenoble; 1998.

25. Santos El, Gomes AMT, Marques SC, Ramos RS, Silva ACSS, Oliveira FT. Comparative study of representations of professional autonomy produced by first and last-period undergraduate nursing students. Rev Latino-Am Enfermagem. 2017;25:e2927. doi: $10.1590 / 1518-8345.1919 .2927$

26. Sá CP. Teoria e pesquisa do núcleo central das representações sociais. In: Estudos de psicologia social: história, comportamento, representações e memória. Rio de Janeiro: EdUERJ; 2015. p. 209-226.

27. Almeida JA, Santos AS, Nascimento MAO, Oliveira JVC, Silva DG, Mendes-Netto RS. Factors associated with food insecurity risk and nutrition in rural settlements of families. Ciênc Saúde Colet. 2017;22(2):479-88. doi: 10.1590/1413-81232017222.27102015

28. Silva FP, Frazão IS, Linhares FMP. Práticas de saúde das equipes dos Consultórios de Rua. Cad Saúde Pública. 2014;30(4):805-14. doi: $10.1590 / 0102-311 \times 00100513$

29. Casa Civil (BR). Lei no 13.714, de 24 de agosto de 2018. Altera a Lei no 8.742, de 7 de dezembro de 1993, para dispor sobre a responsabilidade de normatizar e padronizar a identidade visual do Sistema Único de Assistência Social (Suas) e para assegurar o acesso das famílias e indivíduos em situações de vulnerabilidade ou risco social e pessoal à atenção integral à saúde [Internet]. Brasília: Ministério da Saúde; 1993 [cited 2018 Dec 01]. Available from: http://www.planalto.gov.br/ccivil_03/_Ato2015-2018/2018/Lei/L13714.htm

30. Dimenstein GO. Cidadão de papel: a infância, a adolescência e os direitos humanos no Brasil. 23a ed. São Paulo: Ática; 2011.

31. Foucault M. A hermenêutica do sujeito. 3a ed. São Paulo: Martins Fontes; 2011.

32. Fazel S, Geddes JR, Kushel M. The health of homeless people in high-income countries: descriptive epidemiology, health consequences, and clinical and policy recommendations. Lancet. 2014;384(9953):1529-40. doi: 10.1016/S0140-6736(14)61132-6

33. Argintaru N, Chambers C, Gogosis E, Farrell S, Palepu A, Klodawsky F, et al. A cross-sectional observational study of unmet health needs among homeless and vulnerably housed adults in three Canadian cities. BMC Public Health. 2013;13:577. doi: 10.1186/1471-2458-13-577

34. Halpern SC, Scherer JN, Roglio V, Faller S, Sordi A, Ornell F, et al. Vulnerabilidades clínicas e sociais em usuários de crack de acordo com a situação de moradia: um estudo multicêntrico de seis capitais brasileiras. Cad Saúde Pública. 2017;33(6):e00037517. doi: 10.1590/0102-311x00037517

35. Spadoni L, Machado Júnior CO, Barroso LHM, Boni AL, Faria MRGV, Souza SMB. Addiction profile and social practices among homeless people. Psicol Saber Soc. 2017;6(1):113-28. doi: 10.12957/psi.saber.soc.2017.30670

36. Rosa AS, Brêtas ACP. Violence in the lives of homeless women in the city of São Paulo. Interface (Botucatu). 2015;19(53):275-85. doi: $10.1590 / 1807-57622014.0221$

37. Donoso MTV, Bastos MAR, Faria CR, Costa AA. Ethnographic study on homeless people in a big urban center. Rev Min Enferm 2013;17(4):894-901. doi: 10.5935/1415-2762.20130065

38. Nascimento ARA, Trindade ZA, Gianordoli-Nascimento IF. Homens brasileiros jovens e representações sociais de saúde e doença. Psico-USF. 2011;16(2):203-13. doi: 10.1590/S1413-82712011000200009

39. Aguiar MM, Iriart JAB. Meanings and practices associated with health and illness among the homeless in Salvador, Bahia State, Brazil. Cad Saúde Pública. 2012;28(1):115-24. doi: 10.1590/S0102-311X2012000100012 